DOI

\title{
ДО ПИТАННЯ ПРИЧИН ПІСЛЯОПЕРАЦІЙНОГО РЕЦИДИВУ ВАРИКОЗНОЇ ХВОРОБИ НИЖНІХ КІНЦІВОК
}

\author{
ФВ. Б. Гощинський' ${ }^{1}$ Р. С. Кохан', Р. М. Борис², О. Б. Луговий ${ }^{3}$ \\ ДВНз «Тернопільський державний медичний університет імені І. Я. Горбачевського МОз України»', \\ Інститут народної медицини, \\ Тернопільська міська комунальна лікарня № $2^{3}$
}

РЕЗЮМЕ. У 65 хворих на варикозну хворобу нижніх кінцівок проведено дослідження маркерів ендотеліальної дисфункції до операції, в ранньому (10 днів) та пізньому (60 днів) післяопераційному періоді. Встановлено збільшення показників маркерів ендотеліальної дисфункції як до операції, так і в післяопераційному періоді. Морфологічне дослідження глибоких вен нижніх кінцівок дозволило констатувати, що причиною ендотеліальної дисфункції можуть бути суттєві зміни у структурі всіх шарів стінки вени, особливо ендотеліального шару.

КЛЮчОВІ СлОВА: варикозна хвороба, ендотеліальна дисфункція, морфологічні дослідження.

Вступ. На перший погляд така нескладна, «мала та безпечна» операція як сафенектомія часто призводить до розчарування хірургів через високу частоту рецидивів варикозної хвороби, яка, за даними різних дослідників, сягає 5,0-25,0 \% [1, $7,8,14,15]$. За умов впровадження сучасних діагностичних та лікувальних заходів такий відсоток рецидивів хвороби слід вважати незадовільним.

На сучасному етапі запровадження ультразвукового кольорового дуплексного сканування вен нижніх кінцівок стало «золотим стандартом" діагностики патології вен та дало змогу визначити i запровадити "гемодинамічний підхід" до оцінки стану венозної системи, що полягає в оцінці вираженості, тривалості та топічної діагностики венозних рефлюксів, оцінці діаметра вен, швидкості кровотоку по відповідних анатомічних сегментах венозної системи та інше $[6,11]$.

Це дало можливість виявити індивідуальні гемодинамічні особливості венозної системи нижніх кінцівок та, виходячи з цього, вибрати адекватні методи оперативного втручання. Слід зазначити, що запровадження високоінформативних діагностичних технологій та інноваційних методів оперативного лікування ВХНК значно зменшило кількість післяопераційних рецидивів варикозної хвороби нижніх кінцівок (ПРВХНК). Однак, незважаючи на це, у переважній більшості наукових публікацій основний акцент причин ПРВХНК робиться на тактичних та технічних помилках під час виконання сафенектомії [3-5].

Згідно з даними аналізу результатів оперативних втручань у спеціалізованих клініках, де дотримуються діагностичних, тактичних та технічних принципів лікування ВХНК, певний відсоток ПРВХНК припадає на «несправжній рецидив» $[9,10,12,13]$.

На нашу думку, не можна з певністю стверджувати, що в післяопераційному періоді у па- тофізіологічному та патоморфологічному стані венозної системи нижніх кінцівок відбуваються зміни, які можуть бути ініціаторами ПРВХНК.

Мета дослідження - визначити значення ендотеліальної дисфункції в післяопераційному рецидиві варикозної хвороби нижніх кінцівок.

Матеріал і методи дослідження. Результати дослідження базуються на аналізі 65 хворих, прооперованих з приводу варикозної хвороби нижніх кінцівок. За міжнародною класифікацією CEAP пацієнтів з С2 було 37, з С3 - 23 та із С4- 5 . Вік хворих був $(45 \pm 5,7)$ років. Жінок було 45 , чоловіків- 20.

Функціональний стан глибокої та поверхневої венозної системи нижніх кінцівок визначали за допомогою ультразвукового кольорового дуплексного сканування вен. Для цього був використаний апарат Vivid 3 (Дженерал Електрик, США) з датчиком частотою 5-10 МГц та відповідним стандартним пакетом програмного забезпечення вказаної фірми для обстеження венозної системи. Пацієнтів обстежували у другій половині дня у вертикальному та горизонтальному положеннях. Під час ультразвукового дослідження оцінювали наявність кровотоку у венах, діаметри та форми просвіту вен, їх деформацію та мішкоподібну трансформацію, товщину стінок, однорідність, еластичність клапанів, їх функцію під час навантажувальних гідростатичних проб, наявність рефлюксу крові, тривалість ретроградного потоку по венозних магістралях, а також його поширення на анатомічні сегменти, стан сафено-феморального та сафено-поплітеального співусть. У всіх пацієнтів виявили неспроможність клапана сафено-феморального співустя з різною протяжністю рефлюксу по стовбуру великої підшкірної вени.

Ендовенозну лазерну коагуляцію вен (ЕВЛК) здійснювали вітчизняним портативним висо- 
Огляди літератури, оригінальні дослідження, погляд на проблему

коінтенсивним напівпровідниковим (діодним) лазерним апаратом "Ліка-хірург», виробництва Черкаського МПП «Фотоніка Плюс» із довжиною хвилі 1470 нм, потужністю 10-12,5 Вт. Позицію світловоду контролювали лазерним червоним пілотним випромінюванням, або інтраопераційною ультразвуковою діагностикою. Втручання здійснювали під загальним знеболюванням або спинномозковою анестезією за протоколом, поданим Л. М. Чернухою та співавторами, який включав кросектомію; хірургічну обробку притоків великої і малої підшкірних вен з використанням міні-доступів; ендовазальну лазерну коагуляцію стовбурів підшкірних вен; пересічення і перев'язування перфорантних вен з використанням міні-доступів або за допомогою субфасціальної дисекції вен; катетерну склеротерапію та мініфлебектомію за Мюлером.

Ендотеліальну дисфункцію оцінювали шляхом визначення рівня маркерів ендотеліальної дисфункції: Р-селектину, Е-селектину, тканинного активатора плазміногену, ендотеліну-1, молекули адгезії судинного ендотелію 1 типу (sVCAM-1soluble vascular cellular molecula), циркулюючих ендотеліальних клітин (ЦЕК). Ці показники досліджували у всіх 60 пацієнтів. Забір крові здійснювали інтраопераційно шляхом пункції ліктьової вени передпліччя і стовбура варикозно розширеної великої підшкірної вени, відступаючи від сафено-феморального співустя дистальніше на 2 см. ЦЕК визначали за методикою J. Hladovec в інтерпретації Н. Н. Петрищева і співавт. (2001). Концентрації Р-селектину, Е-селектину, тканинного активатора плазміногену, молекули адгезії судинного ендотелію 1 типу (sVCAM-1-soluble vascular cellular molecula) визначали з використанням наборів фірми "Bender Med Systems" (АВстрія) для імуноферментного аналізу (ІФА) згідно з інструкцією виробника. Концентрацію ендотеліну-1 встановлювали з використанням наборів фірми «Biomedica» (Канада) для ІФА згідно $з$ інструкцією виробника. Оцінку реакції проводили на мікропланшетному напівавтоматичному фотометрі SUNRISE (Тесап, Австрія) за допомогою промивної станції Hydroflex (Tесап, Австрія), що дозволяло стандартизувати ці методи. Контролем були досліджувані показники у 30 здорових людей. Маркери ендотеліальної дисфункції також визначали у ранньому (10 день після операції) та пізньому післяопераційному періоді (60 днів після операції). Кров на дослідження забирали із стегнової вени кінцівки, прооперованої з приводу ВХНК та ліктьової вени.

Для визначення морфологічного стану глибокої венозної системи нижніх кінцівок, під час секційного дослідження у 31 хворого, які мали ва- рикозну хворобу нижніх кінцівок, забрані ділянки стегнової вени, довжиною до 2 см. Гістологічні препарати виготовляли згідно з загальноприйнятими методиками. Фарбування здійснювали гематоксиліном та еозином. Морфометричні дослідження проводили використовуючи систему аналізу гістологічних препаратів. Зображення на монітор комп'ютера виводили з мікроскопу лОМО Біолам за допомогою відеокамери Vision CCD Camera і програми Inter Video Win DVR. Аналіз морфологічних досліджень проведено за допомогою програм VideoTest 5.0 та Microsort Exel на персональному комп'ютері. Підраховували площу ядер, цитоплазми, ядерно-цитоплазматичне співвідношення, середню висоту ендотеліоцитів інтими. Площу ядер ендотеліоцитів визначали за формулою

$$
\mathrm{S}=\Pi_{2} / 4 \text {, }
$$

де S - площа вимірюваної структури, мкм²; D - iї діаметр, мкм. Для структур еліпсоподібної форми використовували формулу

\section{$\mathrm{S}=\left(\Pi \mathrm{R}_{1} \mathrm{R}_{2}\right) / 4$,}

де $\mathrm{S}$ - площа вимірюваної структури, мкм², $\mathrm{R}_{1}$ - більший діаметр, мкм; $\mathrm{R}_{2}$ - менший діаметр, МКм.

Для електронно-мікроскопічних досліджень ділянку венозної стінки попередньо фіксували в 2,5 \% розчині глютаральдегіду з активною реакцією середовища $\mathrm{pH} 7,2-7,4$, приготованому на фосфатному буфері Міллоніга. Постфіксацію шматочків вени здійснювали 1 \% розчином чотириокису осмію на буфері Міллоніга протягом 60 хвилин, після чого проводили дегідратацію матеріалу в спиртах і ацетоні та заливали в епоксидні смоли згідно з загальноприйнятою методикою. Ультратонкі зрізи вени, виготовлені на ультрамікротомі УМПТ-7, фарбували 1 \% водним розчином уранілацетату, контрастували цитратом свинцю згідно з методом Рейнольдса та вивчали в електронному мікроскопі ПЕМ-125 К.

Статистичну обробку цифрових даних здійснювали методом варіаційної статистики. Достовірність різниці середніх величин та їх похибок оцінювали за критеріями Стьюдента-Фішера. Обробку цифрових даних проводили за методом Стьюдента в програмі Exel на персональному комп'ютері. Достовірною вважали імовірність помилки менше 5 \% ( $\leq \leq 0,05)$. Для кожної досліджуваної величини обчислювали середню арифметичну виважену (M) за формулою: $M=(\Sigma \vee \times P) / n$, де $\mathrm{P}$ - число випадків спостереження даної ознаки; V-варіанта.

Результати й обговорення. Аналіз біохімічних маркерів ендотеліальної дисфункції (табл. 1, 2) свідчить про наявність явних ознак ендотеліальної дисфункції (ЕД) у хворих на ВХНК. 
Огляди літератури, оригінальні дослідження, погляд на проблему

Таблиця 1. Біохімічні маркери ЕД до операції в зразках крові з великої підшкірної вени (ВПВ) і ліктьової вени у хворих ВХВНК $(n=60)$.

\begin{tabular}{|c|c|c|c|}
\hline Показник & Контроль $(n=30)$ & ВПВ & Ліктьова вена \\
\hline ЦЕК, Клітин ×104/л & $3,67 \pm 1,47^{*}$ & $7,13 \pm 1,72^{*}$ & $4,6 \pm 1,1^{*}$ \\
\hline sVCAM-1, нг/мл & $248,53 \pm 1,96 *$ & $356,76 \pm 11,78^{*}$ & $339,1 \pm 58,7 *$ \\
\hline Р-селектин, нг/мл & $158,47 \pm 1,61^{*}$ & $188,73 \pm 8,89 *$ & $176,7 \pm 22,5^{*}$ \\
\hline Е-селектин, нг/мл & $40,5 \pm 1,1^{*}$ & $47,47 \pm 4,93^{*}$ & $43,7 \pm 8,6 *$ \\
\hline $\mathrm{t}-\mathrm{PA}, \mathrm{нг} / \mathrm{M} л$ & $3,4 \pm 1,07$ & $3,7 \pm 0,6$ & $2,0 \pm 0,9$ \\
\hline Ендотелін-1, пмоль/л & $2,24 \pm 0,015$ & $1,85 \pm 0,4$ & $1,3 \pm 0,1$ \\
\hline
\end{tabular}

Кількість циркулюючих ендотеліальних клітин у венозній крові ураженої варикозною хворобою нижньої кінцівки виявилась значно вищою, порівняно із венозною кров'ю, взятою з ліктьової вени. Це свідчить про локальність патологічних процесів при ВХНК і доводить високу значимість даного маркера ендотеліальної дисфункції при цій патології.

Також виявлена різниця у показнику SVCAM-1, визначеному у венозній крові, взятій із ВПВ та із ліктьової вени. Це вказує на порушення взаємодії ендотеліоцитів з клітинами периферійної крові. Так, підвищена експресія молекули адгезії sVCAM-1 в стінку вени є ознакою міграції лейкоцитів крізь ендотелій і підтримання запального процесу в ній. Вищезазначене доводить, що в розвитку варикозної хвороби нижніх кінцівок одну з ключових ролей відіграє запалення на тлі функціонально зміненого і активованого ендотелію.

Таблиця 2. Порівняльна характеристика показників ЕД до операції та в післяопераційному періоді (n=60)

\begin{tabular}{|l|c|c|c|c|}
\hline \multicolumn{1}{|c|}{ Показник } & Контроль $(\mathrm{n}=30)$ & До операції & 10 доба після операції & 60 днів після операції \\
\hline ЦЕК, клітин ×104/л & $3,67 \pm 1,44^{*}$ & $7,13 \pm 1,72^{*}$ & $9,53 \pm 1,96^{*}$ & $4,43 \pm 1,09 *$ \\
\hline VСАМ-1, нг/мл & $248,53 \pm 1,93^{*}$ & $356,76 \pm 11,78^{*}$ & $477,4 \pm 18,69^{*}$ & $264,57 \pm 24,13^{*}$ \\
\hline Р-селектин, нг/мл & $158,47 \pm 1,56^{*}$ & $188,73 \pm 8,89^{*}$ & $178,7 \pm 4,54^{*}$ & $157,57 \pm 7,35^{*}$ \\
\hline Е-селектин, нг/мл & $40,5 \pm 1,09^{*}$ & $47,47 \pm 4,93^{*}$ & $33,4 \pm 4,0^{*}$ & $25,26 \pm 3,0 *$ \\
\hline t-РА, нг/мл & $3,4 \pm 1,07$ & $3,7 \pm 0,6$ & $3,6 \pm 1,04$ & $3,9 \pm 1,7$ \\
\hline Ендотелін-1, пмоль/л & $2,24 \pm 0,016$ & $1,85 \pm 0,4$ & $2,78 \pm 0,28$ & $2,46 \pm 0,24$ \\
\hline Примітка. * - $>0,05$. & & \\
\hline
\end{tabular}

При повторному дослідженні маркерів ЕД у ранньому (10 днів) та пізньому (60 днів) післяопераційному періоді ми констатували, що основні показники ЕД залишаються збільшеними, хоча й меншими за доопераційні. Таким чином можна стверджувати, що після виконання сафенектомії ЕД повністю не ліквідується.

Для встановлення причини цього явища ми провели додаткове морфологічне, морфометричне та електронно-мікроскопічне дослідження стану глибокої венозної системи нижніх кінцівок у 31 хворого, який мав варикозну хворобу нижніх кінцівок. Матеріал на дослідження (ділянки стегнової вени довжиною до 2 см) забирали під час секційного дослідження.

У результаті проведених досліджень морфологічного стану глибокої венозної системи у хворих на варикозну хворобу виділено наступні типи морфологічних змін у їхній стінці: гіпертрофія структурних елементів стінки, початкові явища склерозу венозної стінки на фоні гіпертрофії, початкові явища атрофії на фоні вираженого склерозу та виражена атрофія стінки.
У першій категорії хворих зміни внутрішньої оболонки були пов'язані із ендотеліальним шаром і розвитком артеріолізації венозної стінки, що проявлялось у появі валикоподібних ділянок, ендотеліоцитів, які виступають у просвіт судини. Ядра ендотеліоцитів виглядали світлими. Спостерігали і невеликі ділянки десквамації ендотелію, утворення з багатоядерних клітин симпластоподібної структури і ділянки гіпертрофії субендотеліального шару. При цьому субендотеліальний шар розвинутий помірно, тоді як м'язовий шар побудований із двох добре диференційованих шарів м'язових волокон, що формують внутрішній циркулярний та зовнішній повздовжній шари, волокна гіпертрофовані, поміж ними відмічається інтерфасцикулярний склероз. Адвентиційна оболонка тонка, місцями не візуалізується. Зовнішня і внутрішня еластичні мембрани візуалізуються відмінно. У верхній третині великої підшкірної вени, в пригирловій ділянці, вказані елементи були більш виражені, там же з'являвся і додатковий середній шар м'язової оболонки з косим напрямком волокон (рис. 1, 2). 
Огляди літератури, оригінальні дослідження, погляд на проблему

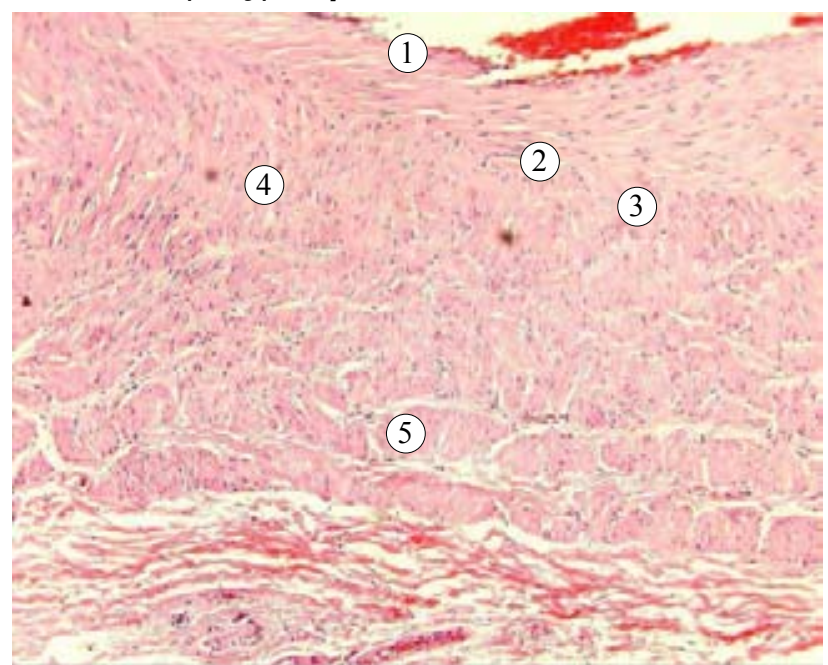

Рис. 1. Гіпертрофія стінки вени: ендотеліальні клітини (1) ; базальна мембрана (2); субендотеліальний шар (3). Медіа представлена внутрішнім циркулярним (4) та зовншішнім повздовжнім (5) шарами волокон. Гематоксилін - еозин. Збільшення х 100.

В субендотеліальному шарі відмічається деяке збільшення вмісту глікозаміногліканів. Клапани вен характеризувались наявністю в них добре розвиненого еластичного компонета сполучної тканини. У деяких випадках в клапанах візуалізувались ділянки двосторонньої епітелізації.

У хворих другої групи при вивченні матеріалу ми спостерігали зміни, що характеризують інтенсивний розвиток колагенових волокон, появу сітки колагенових волокон на межі між внутрішнім - ендотеліальним та середнім - м'язовим шарами, причому напрямок колагенових волокон був паралельним до ендотелію, а у деяких випадках - під кутом до нього. Еластичні волокна в м'язовому шарі були переважно незмінені, зрідка

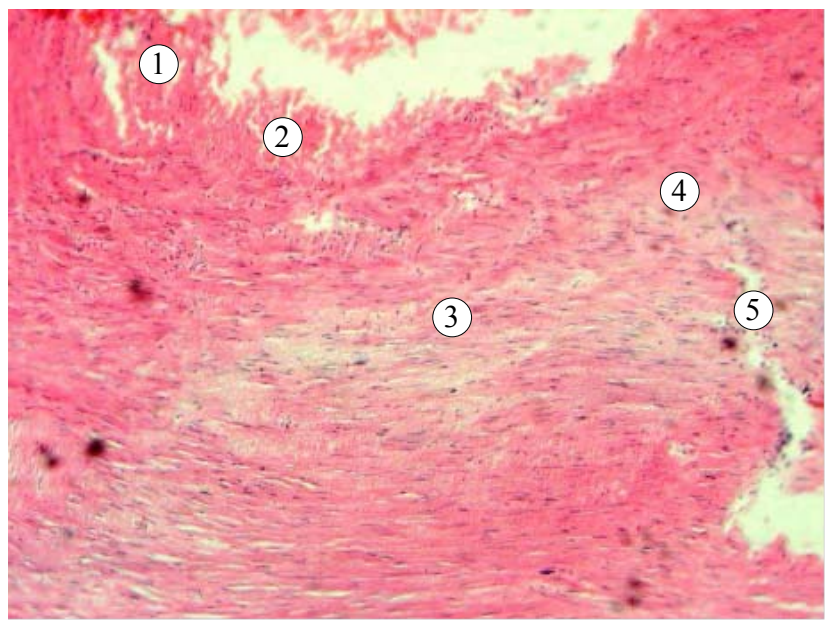

Рис. 3. Гіпертрофія ендотелію (1), ділянки десквамації (2), розвиток колагенових волокон (3), явища колагенозу (4), фрагментація окремих колагенових волокон (5). Гематоксилін-еозин. Збільшення х 100.

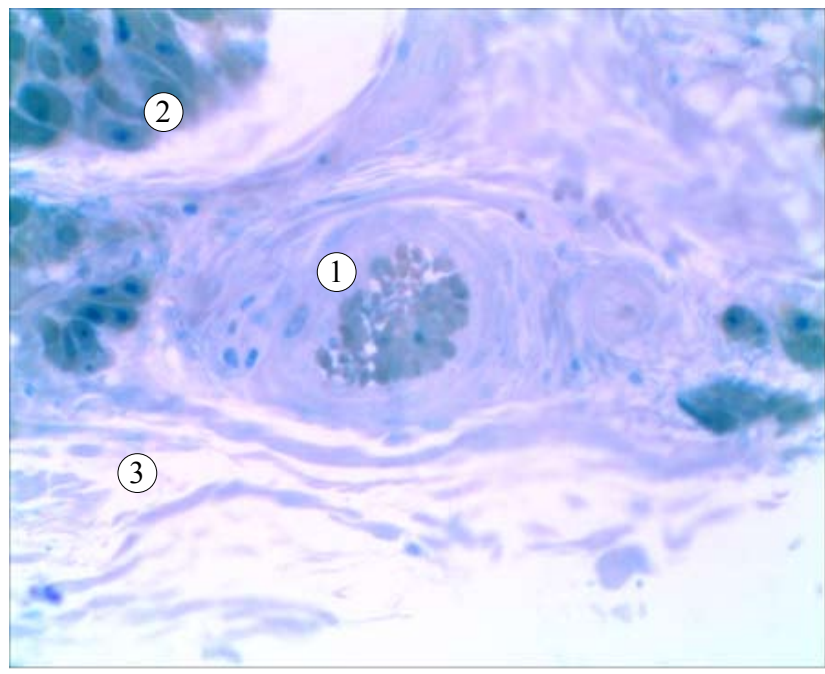

Рис. 2. Артеріалізація венозної стінки (1), просвітлення ядер ендотеліоцитів (2), інтерфасцикулярний склероз (3). Ультратонкий зріз. 36. х 400.

наставала їх фрагментація. Вміст кислих глікозаміногліканів був у межах норми. Зустрічались у м'язовій оболонці і судини, що мали типову будову, в окремих відмічався гіаліноз. В адвентиції візуалізуються повздовжні пучки гладких міоцитів, добре розвинуті еластичні мембрани в артеріях судини, звичайна товщина і кількість колагенових волокон при відсутності склеротичних змін, вміст кислих глікозаміногліканів у межах норми. Колагенові волокна достатньо товсті, переважно інтактні (рис. 3,4$)$.

При цьому будова ендотеліального шару практично не відрізняється від аналогічної у першій групі. Має місце потовщення субендотеліального шару, в деяких випадках рівномірне по всій

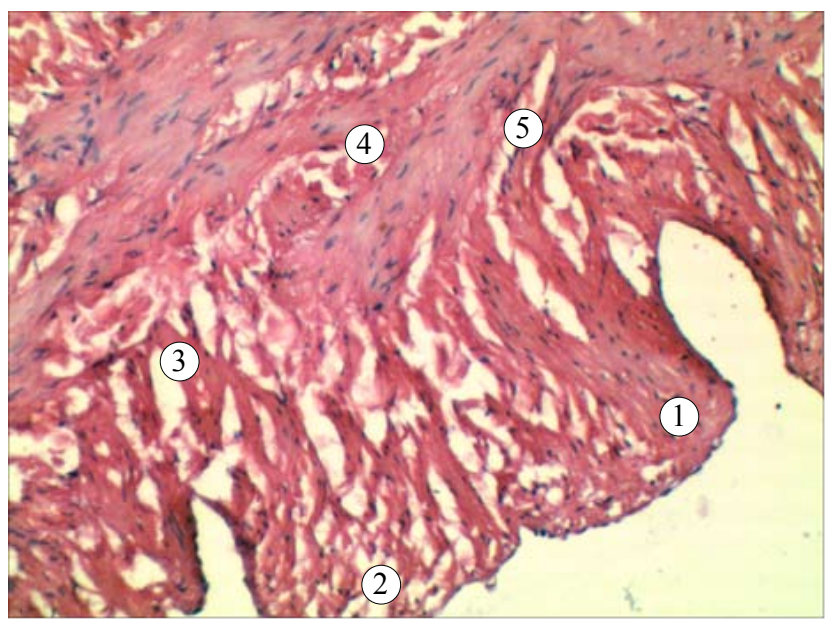

Рис. 4. Гіпертрофія ендотелію (1), ділянки десквамації (2), розвиток колагенових волокон (3), явища колагенозу (4), фрагментація окремих колагенових волокон (5). Гематоксилін-еозин. Збільшення х 100. 
Огляди літератури, оригінальні дослідження, погляд на проблему

окружності судини скупчення у вигляді подушки гладких міоцитів з веретеноподібними ядрами, розміщеними вздовж осі судини. Ділянки десквамації ендотелію в місцях його гіпертрофії. В субендотеліальному шарі відмічається накопичення кислих глікозаміногліканів, початковий склероз за рахунок розвитку колагенових волокон. Еластичні волокна на межі з м'язовою оболонкою потовщувались, в деяких випадках навіть з явищами початкового гіалінозу.

М'язова оболонка містить гладкі міоцити 3 ділянками їх розволокнення, найвираженіші в зовнішніх шарах оболонки. Склеротичні зміни м'язової оболонки були виражені в різних ділянках венозної стінки. На деяких ділянках спостерігали розволокнення м'язової оболонки 3 розділенням їх сполучною тканиною. Еластичні волокна були гіпертрофованими. В адвентиційній оболонці візуалізувались склероз з потовщенням та гомогенізацією (однорідністю) еластичних волокон.

Для третьої групи пацієнтів характерним було переважання процесів атрофії елементів судинної стінки на фоні склерозу (рис. 5).

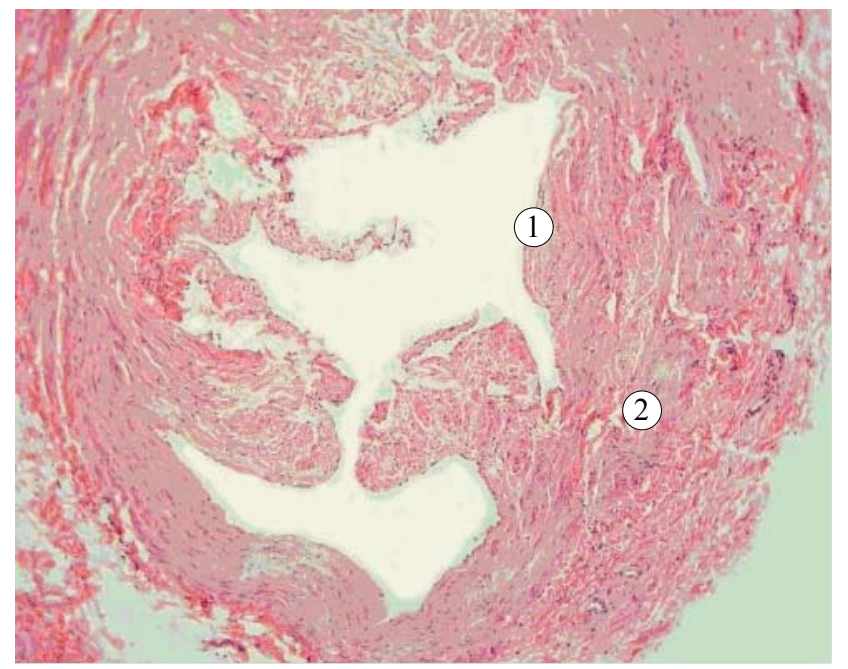

Рис. 5. Початкова атрофія (1) венозної системи на фоні вираженого склерозу (2). Гематоксилін-еозин. Збільшення x 100.

Товщина судинної стінки була різною та характеризувалася наявністю ділянок у вигляді валикоподібних потовщень, спостерігалися ділянки десквамації ендотелію. В окремих ділянках спостерігали валикоподібні потовщення субендотеліального шару, до якого прилягали гладкі міоцити з ядрами округлої форми, випинання ендотелію в просвіт судин. Субендотеліальний шар містив велику кількість кислих глікозаміногліканів. Спостерігали фібриноїдний та мукоїдний набряк сполучної частини внутрішньої оболонки вени з явищами метахромазії і гомогенізації кола- генових волокон, набряк і розволокнення еластичних волокон внутрішньої еластичної мембрани. М'язова оболонка характеризувалася різко вираженими атрофічними змінами: стоншанням міоцитів, еластозом та розволокненням. У ряді випадків м'язова оболонка була представлена окремими острівками гладких міоцитів, що лежать між товстими та грубими колагеновими волокнами, в ряді - відсутня повністю, в ряді стоншена до 2-3 шарів міоцитів. Міоцити містили гіпербазофільні, часто спіралеподібно закручені дуже тонкі ядра. У місцях вкрай стоншеної стінки в м'язовій оболонці зустрічалися ділянки без міоцитів. Адвентиційна оболонка характеризувалася вираженими склеротичними змінами, еластозом, гіалінозом. У ряді випадків у цій же групі пацієнтів були виражені характерні атрофічні зміни венозної стінки (рис. 6).

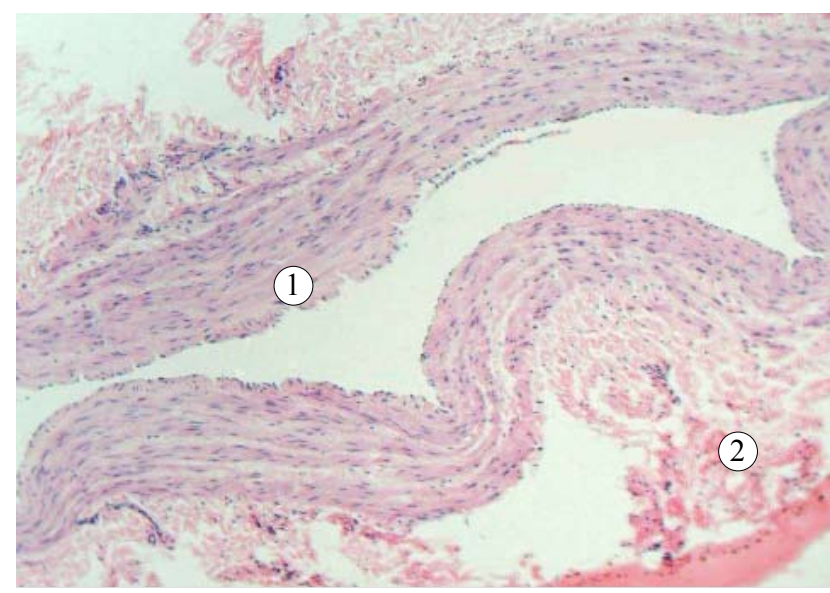

Рис. 6. Виражена атрофія (1) венозної системи на фоні вираженого склерозу (2). Гематоксилін-еозин. Збільшення х 100.

У внутрішній оболонці спостерігалось повне руйнування еластичних елементів з накопиченням у субендотеліальному шарі великої кількості кислих глікозаміногліканів. На великому протязі судинної стінки відмічалося істотне стоншення м'язової оболонки з явищами еластозу і збільшення кількості колагенових волокон. У деяких випадках міоцити були відсутні, а ті, які збереглися, набували будови з різким стоншенням, деяким видовженням, спіральним закручуванням чи деформацією ядер. В адвентиції спостерігали деяке потовщення еластичних і колагенових волокон.

Отримані дані свідчать про те, що у хворих на варикозну хворобу в патологічний процес втягуються глибока венозна система нижніх кінцівок 3 розвитком у них структурних змін. Зміни стосуються всіх шарів судинної стінки, мають різноманітний характер - гіпертрофія, атрофія та склероз. Розвиток атрофії та склерозу стінки глибокої венозної системи свідчить про зниження іiї пружноелас- 
Огляди літератури, оригінальні дослідження, погляд на проблему

тичних властивостей і $\epsilon$ морфологічною основою функціональної венозної недостатності та прогресування порушення венозного відтоку по глибоких венах. Виявлену у частини хворих гіпертрофію венозної стінки можна розцінювати як компенсаторну реакцію у відповідь на гемодинамічні порушення у венах нижніх кінцівок: гіпертрофія призводила до підвищення тонусу стінки вени і сприяла на певних етапах захворювання збереженню нормального венозного відтоку. Суттєві зміни спостерігали і в ендотеліальному шарі, вони проявлялися десквамацією ендотелію, на окремих ділянках виявляли валикоподібні потовщення субендотеліального шару, до якого прилягали гладкі міоцити

\section{ЛІТЕРАТУРА}

1. Венгер І. К. Основні причини формування рецидиву варикозної хвороби вен нижніх кінцівок після хірургічного лікування / І. К. Венгер, М. В. Чорненький, С. Я. Костів // Шпитальна хірургія. - 2011. - № 2. С. $18-23$.

2. Гощинський В. Б. Деякі питання патогенезу варикозної хвороби нижніх кінцівок: дані гістологічних, морфометричних та електронно-мікроскопічних досліджень / В. Б. Гощинський, Р. С. Кохан // Вісник наукових досліджень. - 2015. - № 4. - С. 50-55.

3. Сафонов В. А. Рецидив варикозной болезни. Причины возникновения, методы диагностики и лечения /В. А. Сафонов, Д. Ф. Громацкий, С. В. Ненарочнов // Бюллетень СО РАМН. - 2013. - Т. 33, № 3. - С. 46-50.

4. Смирнов А. А. Рецидив варикозного расширения вен нижних конечностей / А. А. Смирнов, Л. К. Куликов, Ю. А. Привалов // Новости хирургии. -2015. - № 23 (4). C. 447-451.

5. Ставер Е. В. Эпидемиология рецидива варикозной болезни нижних конечностей / Е. В. Ставер, М. П. Потапов // Здоровье и образование в XXI веке. - 2011. T. 13, № 1. - С. 65-69.

6. Хрыщанович В. А. Рецидив варикозной болезни: неадекватное хирургическое лечение по-прежнему остается проблемой? / В. А. Хрыщанович, С. И. Третьяк, А. В. Романович // Флебология. - 2010. - № 3. - С. 71-73.

7. Чернуха Л. М. Проблема варикозной болезни нижних конечностей сегодня. Наиболее дискуссионные вопросы / Л. М. Чернуха, А. А. Гуч, А. О. Боброва // Хірургія України. - 2010. - № 1. - С. 42-49.

8. Ali S. M. Results and significance of colour duplex assessment of the deep venous system in recurrent vari- з ядрами округлої форми, випинання ендотелію в просвіт судин та вміст у субендотеліальному шарі великої кількісті кислих глікозаміногліканів.

Висновки. Виходячи із наших попередніх досліджень [2] можна стверджувати, що у венозній системі нижніх кінцівок при ВХ наявні системні патоморфологічні та патофізіологічні зміни, що може бути однією з причин післяопераційного рецидиву варикозної хвороби.

Перспективи подальших досліджень. Виникає необхідність у розробці критеріїв для прогнозування післяопераційного рецидиву варикозної хвороби, а також засобів для запобігання його розвитку.

cose veins / S. M. Ali, M. J. Callam // European Journal of Vascular and Endovascular Surgery. - 2007. - Vol. 34. P. 97-101.

9. Allaf N. Recurrent varicose veins after inadequate surgery/N. Allaf, M. Welch //Phlebology.-2005.-Vol. 20.P. $138-140$.

10. Blomgren L. Recurrent varicose veins: incidence, risk factors and groin anatomy / L. Blomgren, G. Johansson, A. Dahlberg-Akerman // Eur. J. Vasc. Endovasc. Surg. 2004. - Vol. 27. - P. 269-274.

11. Duplex ultrasound investigations of the veins in chronic venous disease of the lower limbs - UIP Consensus Document / A. Cavezzi, N. Labropoulos, H. Partsch [et al.] // European Journal of Vascular and Endovascular Surgery. - 2006. - Vol. 31. - P. 83-92.

12. Perrin M. R. Recurrent varices after surgery (REVAS): a consensus document / M. R. Perrin, J. J. Guex, C. V. Ruckley // Cardiovasc Surg. - 2000. - Vol. 8. P. 233-245.

13. Randomized clinical trial comparing endovenous laser ablation and stripping of the great saphenous vein with clinical and duplex outcome after 5 years / L. Rasmussen [et al.] // J. Vasc. Surg. - 2013. - Vol. 58, № 2. P. 421-426.

14. Robertson L. Epidemiology of chronic venous disease / L. Robertson, C. Evans, F. G. Fowkes // Phlebology. 2008. - Vol. 23. - № 3. - P. 103-111.

15. The care of patients with varicose veins and associated chronic venous diseases: clinical practice guidelines of the Society for Vascular Surgery and the American Venous Forum / P. Gloviczki [et al.] // J. Vasc. Surg. - 2011. Vol. 53, № 5. - P. 28-48. 
I. Horbachevsky Ternopil State Medical University', Institute of Traditional Medicine, Ternopil Municipal Hospital № $2^{3}$

SUMMARY. In 65 patients with varicose disease lower limbs research of markers of endothelial dysfunction (ED) before operation, after operation (10 days) and in long-term (60 days) the postoperative period was made. It was established the increase of markers of (ED) as before surgery and in the postoperative period. Morphological study of the deep veins of the lower limbs determined that the cause of (ED) may be significant changes in the structure of all the layers of the wall of the vein, especially endotelial layer.

KEY WORDS: varicose disease, endothelial dysfunction, morphological research. 